\title{
PENINGKATAN KETERAMPILAN PEMBUATAN TAS MELALUI MODEL PEMBELAJARAN EKSPLISIT
}

\author{
Laila Nurul Himmah \\ SLB Negeri 1 Yogyakarta \\ lailanurulh@gmail.com
}

\begin{abstract}
Intisari
Penelitian ini bertujuan untuk mengetahui peningkatan hasil belajar keterampilan tata busana materi pembuatan tas pada anak tunagrahita ringan dengan menggunakan model pembelajaran eksplisit. Penelitian ini dilaksanakan pada peserta didik kelas VII SMPLB-C Negeri 1 Yogyakarta dengan jumlah dua peserta didik pada bulan Maret hingga April 2018. Penelitian ini menggunakan metode penelitian tindakan kelas (Class Action Research). Penelitian ini terdiri dari dua siklus, di mana setiap siklus terdiri dari 2 kali pertemuan. Analisis keberhasilan penelitian dilakukan secara individu, yaitu per aspek per anak karena perkembangan anak tunagrahita tidak dapat dibandingkan dengan anak lain melainkan perkembangan pada dirinya sendiri. Hasil penelitian menunjukkan adanya peningkatan hasil belajar keterampilan tata busana materi pembuatan tas pada anak tunagrahita ringan kelas VII SMPLB-C Negeri 1 Yogyakarta yang dilakukan dengan menggunakan model pembelajaran eksplisit.
\end{abstract}

Kata kunci: anak tunagrahita ringan, keterampilan tata busana, pembelajaran eksplisit.

\section{PENDAHULUAN}

Anak berkebutuhan khusus adalah anak yang memiliki keterbatasan pada dirinya. Salah satu keterbatasan tersebut adalah keterbatasan mental atau disebut tunagrahita. Kondisi ini menyebabkan individu yang bersangkutan mengalami hambatan dalam belajar dan melakukan berbagai fungsi dalam kehidupan serta penyesuaian diri. Berbagai upaya dilakukan untuk membekali anak tunagrahita agar mereka bisa bersosialisasi dalam kehidupan yang lebih layak di masyarakat.

SLB Negeri 1 Yogyakarta merupakan salah satu sekolah yang melayani pendidikan bagi anak-anak yang memiliki kekurangan, salah satunya bagi anak tunagrahita ringan dan sedang. Jenjang pendidikan yang ada untuk anak tunagrahita di SLB Negeri 1 Yogyakarta, yaitu TKLB, SDLB, SMPLB, dan SMALB. Setelah selesai mengikuti pendidikan pada jenjang SMALB-C, biasanya anak tunagrahita jarang sekali untuk meneruskan pendidikan ke jenjang pendidikan yang lebih tinggi. Hal ini dikarenakan sangat sedikit sekali sekolah untuk anak tunagrahita dan faktor biaya yang sangat besar. Selain itu, anak 
tunagrahita juga mengalami kesulitan dalam mencari pekerjaan, dikarenakan kekurangan yang dimilikinya.

Sekolah Luar Biasa-C (SLB-C) merupakan tempat bagi para anak tunagrahita mengembangkan keterampilannya. Pelajaran yang diberikan lebih difokuskan pada keterampilan yang diharapkan dapat memberikan bekal untuk berwirausaha bagi anak tunagrahita. Keterampilan yang diberikan di antaranya tata boga, tata busana, laundry, kriya kayu, cuci motor dan lain lain. Namun kenyataan yang ada pada Sekolah Luar Biasa Negeri 1 Yogyakarta, anak tunagrahita belum menguasai keterampilan yang diberikan.

Keterampilan menjahit yang diberikan pada pelajaran tata busana difokuskan pada pembuatan lenan rumah tangga dan tas. Dalam penelitian ini dikhususkan pada pembuatan tas untuk suvenir, karena tas untuk suvenir merupakan jenis tas yang sering mendapat pesanan. Modelnya yang sederhana dan perpaduan warna serta motif menjadikan tas terlihat cantik. Selain itu pembuatannya sangat mudah, bahannya mudah didapatkan, dan peralatannya pun sudah ada.

Selama ini peneliti melihat di kelas VII SMPLB Negeri 1 Yogyakarta pada mata pelajaran tata busana belum mencapai hasil yang maksimal. Hal ini disebabkan karena anak tunagrahita ringan kesulitan dalam memahami konsep perintah, sehingga pada mata pelajaran tata busana perlu diterapkan model pembelajaran eksplisit.

Model pembelajaran eksplisit merupakan model pembelajaran yang mengarah pada prosedural. Model pembelajaran ini digunakan untuk menyampaikan pelajaran yang ditransformasikan langsung oleh guru kepada peserta didik. Dengan menggunakan model pembelajaran eksplisit, penyampaian proses keterampilan diharapkan dapat lebih mudah diberikan oleh guru. Karakteristik anak tunagrahita ringan cenderung mengalami kesulitan dalam menerima, memproses, dan mengingat berbagai stimulus yang diterima. Kesulitan tersebut dapat ditanggulangi dengan memberikan proses belajar secara langsung dan berulang-ulang. Proses belajar tersebut akan membantu mereka untuk dapat melakukan berbagai stimulus yang diberikan.

Berdasarkan kondisi pada kelas VII SMPLB-C Negeri 1 Yogyakarta, penulis merasa perlu meningkatkan hasil belajar keterampilan tata busana materi pembuatan tas pada anak tunagrahita ringan. Peningkatan keterampilan dikhususkan pada pembuatan tas untuk suvenir dengan menggunakan model pembelajaran eksplisit pada anak tunagrahita ringan kelas VII SMPLB-C Negeri 1 Yogyakarta. Model pembelajaran eksplisit diberikan agar peserta didik mampu menjahit tas tanpa bimbingan guru.

Berdasarkan latar belakang tersebut, maka dalam penelitian ini dirumuskan masalah sebagai berikut: "Bagaimanakah meningkatkan hasil belajar 
keterampilan tata busana materi pembuatan tas pada anak tunagrahita ringan kelas VII SMPLB Negeri 1 Yogyakarta melalui model pembelajaran eksplisit?”

Penelitian ini menggunakan beberapa kajian teori yang melandasinya, di antaranya: (a) tunagrahita, (b) model pembelajaran eksplisit, dan (c) Keterampilan Tata Busana. Ketiga kajian teori tersebut akan diuraikan sebagai berikut.

\section{A. Tunagrahita}

Tunagrahita merupakan istilah yang digunakan untuk menyebut anak yang mempunyai kemampuan intelektual di bawah rata-rata. Retardasi mental atau dikenal dengan istilah disabilitas inteligensia (di Indonesia dikenal dengan nama tunagrahita) adalah individu yang mengalami keterbatasan mental (Jamaris, 2010 : 269). Pada masa awal perkembangan, hampir tidak ada perbedaan antara anak-anak tunagrahita dengan anak yang memiliki kecerdasan rata-rata. Akan tetapi, semakin lama perbedaan pola perkembangan antara anak tunagrahita dengan anak normal semakin terlihat jelas.

Tunagrahita atau keterbelakangan mental merupakan kondisi di mana perkembangan kecerdasan individu yang mengalami hambatan sehingga tidak mencapai tahap perkembangan yang optimal. Ada beberapa karakteristik umum tunagrahita yang dapat dipelajari (Somantri, $2007: 105$ ).

Pertama, keterbatasan inteligensi. Inteligensi merupakan fungsi yang kompleks yang dapat diartikan sebagai kemampuan untuk mempelajari informasi dan keterampilan menyesuaikan diri dengan masalah-masalah dan situasi-situasi kehidupan baru, belajar dari pengalaman masa lalu, berpikir abstrak, kreatif, dapat menilai secara kritis, menghindari kesalahan-kesalahan, mengatasi kesulitan-kesulitan, serta kemampuan untuk merencanakan masa depan. Anak tunagrahita memiliki kekurangan dalam semua hal tersebut.

Kedua, keterbatasan sosial. Selain keterbatasan inteligensi, anak tunagrahita juga memiliki kesulitan dalam mengurus diri sendiri dalam masyarakat. Anak tunagrahita cenderung berteman dengan anak yang lebih muda usianya, ketergantungan dengan orang tua sangat besar, tidak mampu memikul tanggung jawab sosial dengan bijaksana, sehingga mereka harus selalu dibimbing dan diawasi.

Ketiga, keterbatasan fungsi-fungsi mental lainnya. Anak tunagrahita memerlukan waktu lebih lama untuk menyelesaikan reaksi pada situasi yang baru dikenalnya. Anak tunagrahita tidak dapat menghadapi sesuatu kegiatan atau tugas dalam jangka waktu yang lama. Anak tunagrahita memiliki keterbatasan juga dalam penguasaan bahasa. Selain itu, anak tunagrahita kurang mampu untuk mempertimbangkan sesuatu, membedakan antara yang baik dan buruk, serta membedakan yang benar dan salah. 
Pengelompokan pada umumnya didasarkan pada taraf inteligensi. Kemampuan inteligensi anak tunagrahita kebanyakan diukur dengan tes Standford Binet dan Skala Weschler (WISC). Tuna grahita dibagi ke dalam tiga kelompok.

Pertama, tunagrahita ringan disebut juga moron atau debil. Kelompok ini memiliki IQ antara 68-52 menurut Skala Binet, sedangkan menurut Skala Weschler (WISC) memiliki IQ 69-55. Mereka masih dapat belajar membaca, menulis, dan berhitung sederhana. Dengan bimbingan dan pendidikan yang baik, anak tunagrahita ringan akan dapat memperoleh penghasilan untuk dirinya sendiri. (Somantri, $2007:$ 106)

Kedua, tunagrahita sedang disebut juga imbesil. Kelompok ini memiliki IQ 51-36 pada Skala Binet dan 54-40 menurut Skala Weschler (WISC). Anak tunagrahita sedang bisa mencapai perkembangan mental agesampai kurang lebih 7 tahun. Mereka dapat dididik untuk mengurus dan melindungi diri sendiri dari bahaya seperti menghindari kebakaran, berjalan di jalan raya, berlindung dari hujan, dan sebagainya.(Apriyanto, 2012:32)

Ketiga, tunagrahita berat. Kelompok anak tunagrahita berat sering disebut idiot. Kelompok ini dapat dibedakan lagi antara anak tunagrahita berat dan sangat berat. Tunagrahita berat (sereve) memiliki IQ antara 32-20 menurut Skala Binet dan antara 39-25 menurut Skala Weschler (WISC). Tunagrahita sangat berat (profound) memiliki IQ di bawah 19 menurut Skala Binet dan IQ di bawah 24 menurut Skala Weschler (WISC). Kemampuan mental maksimal yang dapat dicapai kurang dari tiga tahun atau empat tahun. (Wardani, 1996:22). Anak tunagrahita berat memerlukan bantuan perawatan secara total dalam hal berpakaian, mandi, makan, dan lain-lain. Bahkan mereka memerlukan perlindungan dari bahaya sepanjang hidupnya (Apriyanto, 2012:32).

\section{B. Model Pembelajaran Eksplisit}

Untuk membelajarkan peserta didik yang sesuai dengan gaya belajar mereka sehingga tujuan pembelajaran dapat dicapai dengan optimal, maka ada berbagai model pembelajaran yang perlu diterapkan dalam kegiatan pembelajaran. Dalam praktiknya, harus ingat bahwa tidak ada model pembelajaran yang paling tepat untuk segala situasi dan kondisi. Oleh karena itu, dalam memilih model pembelajaran yang tepat haruslah memperhatikan kondisi peserta didik, sifat materi bahan ajar, fasilitas media yang tersedia, dan kondisi guru itu sendiri. Dalam kaitan ini, penulis menyajikan model pembelajaran eksplisit. Setiap model pembelajaran mengarahkan kita ke dalam mendesain pembelajaran untuk membantu peserta didik sedemikian rupa sehingga tujuan pembelajaran tercapai (Trianto, 2010: 22).

Merujuk pada hal ini, perkembangan model pembelajaran terus mengalami perubahan dari model tradisional menuju model yang lebih modern. Model 
pembelajaran berfungsi untuk memberikan situasi pembelajaran yang tersusun rapi untuk memberikan suatu aktivitas kepada peserta didik guna mencapai tujuan pembelajaran.

Model explicit instruction merupakan suatu pendekatan pembelajaran yang dapat membantu peserta didik dalam mempelajari keterampilan dasar dan memperoleh informasi yang dapat diajarkan selangkah demi selangkah. Pendekatan pembelajaran ini sering disebut model pembelajaran langsung. Model explicit instruction adalah salah satu pendekatan pembelajaran yang dirancang khusus untuk menunjang proses belajar peserta didik yang berkaitan dengan pengetahuan deklaratif dan prosedural yang terstruktur dengan baik yang dapat diajarkan dengan pola kegiatan yang bertahap, selangkah demi selangkah (Arends dalam Trianto, $2010: 41$ ).

Model explicit instruction memiliki kelebihan, diantaranya (a) guru dapat mengendalikan isi materi dan urutan informasi yang diterima oleh peserta didik sehingga dapat mempertahankan fokus mengenai apa yang harus dicapai oleh peserta didik, (b) dapat diterapkan secara efektif dalam kelas yang besar maupun kecil, (c) dapat digunakan untuk menekankan poin-poin penting atau kesulitankesulitan yang mungkin dihadapi peserta didik sehingga hal-hal tersebut dapat diungkapkan, (d) menjadi cara yang efektif untuk membelajarkan informasi dan pengetahuan faktual yang sangat terstruktur; (e) merupakan cara yang paling efektif untuk membelajarkan konsep dan keterampilan eksplisit kepada peserta didik yang berprestasi rendah, (f) menjadi cara untuk menyampaikan informasi yang banyak dalam waktu yang relatif singkat yang dapat diakses secara setara oleh seluruh peserta didik, dan (g) memungkinkan guru untuk menyampaikan ketertarikan pribadi mengenai mata pelajaran (melalui presentasi yang antusias) yang dapat merangsang ketertarikan dan antusiasme peserta didik.

\section{Keterampilan Tata Busana}

Keterampilan adalah kemampuan melakukan pola-pola tingkah laku yang kompleks dan tersusun rapih secara mulus dan sesuai dengan keadaan untuk mencapai hasil tertentu (Reber dalam Syah, 2009:119). Tata busana merupakan salah satu mata pelajaran untuk meningkatkan keterampilan peserta didik.

Keterampilan yang diberikan pada pelajaran tata busana dengan menggunakan metode latihan dapat terbagi dua yaitu keterampilan intelektual dan keterampilan motorik. Keterampilan intelektual adalah keterampilan pengetahuan untuk melaksanakan atau menyelesaikan sesuatu secara pasif. Dalam pelajaran tata busana, keterampilan ini dapat meningkatkan pengetahuan peserta didik mengenai cara-cara pengelolaan, pembuatan, dan penyajian produk.Sedangkan keterampilan motorik adalah keterampilan mengerjakan sesuatu secara aktif. 


\section{METODE}

Penelitian ini menggunakan metode penelitian tindakan kelas (class action research). Penelitian ini dilakukan dengan pemberian siklus. Setiap siklus mempunyai empat kegiatan utama yaitu perencanaan, tindakan, pengamatan, dan refleksi. Kegunaan penelitian tindakan ini adalah untuk meningkatkan hasil belajar keterampilan tata busana materi pembuatan tas untuk suvenir. Model pembelajaran yang digunakan adalah model explicit instruction dimana pembelajaran akan dilakukan secara langsung dan berulang-ulang.

Penelitian ini dilaksanakan di Sekolah Luar Biasa (SLB) Negeri 1 Yogyakarta. Observasi awal dilakukan pada bulan Februari 2018 dan penelitian dilakukan pada bulan Maret 2018 sampai April 2018. Subjek dalam penelitian ini adalah peserta didik kelas VII SMPLB Negeri 1 Yogyakarta semester 2 tahun pelajaran 2017/2018 dengan jumlah 2 orang yang terdiri dari 1 laki-laki dan 1 perempuan.

Penelitian ini menganalisis cara meningkatkan hasil belajar keterampilan tata busana materi pembuatan tas untuk suvenir pada anak tunagrahita ringan kelas VII SMPLB Negeri 1 Yogyakarta melalui model pembelajaran eksplisit. Instrumen pengumpulan data yang digunakan dalam penelitian tindakan ini yaitu observasi, catatan lapangan, wawancara dan dokumentasi penelitian. Pengambilan data dilakukan dengan cara mengamati kegiatan keterampilan tata busana materi pembuatan tas untuk suvenir. Dalam penelitian ini dilaksanakan dua siklus setiap siklusnya terdapat 2 kali pertemuan. Pada siklus pertama, peserta didik melakukan praktik pembuatan tas untuk suvenir dengan bantuan guru dan pada siklus kedua, peserta didik melakukannya dengan sendiri. Upaya meningkatkan hasil belajar keterampilan tata busana materi pembuatan tas untuk suvenir dilakukan pada semester 2 tahun ajaran 2017/2018 yang dilaksanakan setiap hari di ruang kelas tata busana.

Teknik analisis data yang dilakukan adalah analisis data kualitatif dan kuantitatif. Keberhasilan penelitian disimpulkan dengan menggunakan analisis persentase dinyatakan berhasil jika persentase penilaian hasil belajar keterampilan tata busana materi pembuatan tas $>70 \%$, ini berarti hasil belajar keterampilan tata busana materi pembuatan tas untuk suvenir pada anak berkebutuhan khusus dengan tingkat tunagrahita ringan dapat meningkat setelah dilakukannya penelitian. Penetapan keberhasilan persentase ini dilandaskan pada kemampuan yang dimiliki anak dengan tingkat tunagrahita ringan cenderung mengalami kesulitan dalam menerima, memproses, dan mengingat berbagai stimulus yang diterima. 


\section{HASIL PENELITIAN DAN PEMBAHASAN \\ Hasil Penelitian}

Sebelum dilakukannya siklus, peneliti mengadakan obeservasi mengenai kondisi kemampuan peserta didik kepada kolaborator. Hasil observasi awal adalah pada saat peserta didik berada di kelas VII awal semester 2, sudah diberikan pelajaran pembuatan tas untuk suvenir maka tes awal yang diberikan yaitu berupa praktik pembuatan tas untuk suvenir. Pada tes awal yang diberikan hasil belajar keterampilan tata busana membuat tas untuk suvenir belum dimiliki secara maksimal oleh peserta didik. Pada siklus I, peneliti bersama kolaborator menerapkan kegiatan sesuai dengan rencana pembelajaran yang telah disusun.

Ba merupakan anak yang aktif dalam mengikuti kegiatan pembelajaran. Ia senang sekali mengajukan pertanyaan, namun kadang kala sangat senang bercanda, sehingga guru harus selalu mengingatkannya. $\mathrm{Ba}$ mengalami peningkatan hasil belajar keterampilan tata busana materi pembuatan tas untuk suvenir sebesar 11,5\%. Sudah terdapat peningkatan tetapi peningkatan yang dialami Ba belum maksimal dan belum mencapai target sebesar $70 \%$.

Kemudian, Pu juga peserta didik yang sering ditemui tidak fokus, ia sering termenung dan tidak memperhatikan guru. $\mathrm{Pu}$ jarang mengajukan pertanyaan, namun ia bisa menjawab pertanyaan yang diberikan guru. $\mathrm{Pu}$ mengalami peningkatan hasil belajar keterampilan tata busana materi pembuatan tas untuk suvenir sebesar $9 \%$. Sudah terdapat peningkatan, tetapi peningkatan yang dialami Pu belum maksimal dan belum mencapai target sebesar $70 \%$.

Berdasarkan hasil pada pengamatan siklus I, peneliti dan kolaborator melihat peningkatan peserta didik masih kurang optimal, karena dalam pembuatan tas untuk suvenir, peserta didik masih mendapatkan bimbingan guru. Berdasarkan hal tersebut, latihan secara mandiri akan dilakukan pada siklus II.

Pada siklus II permasalahan yang timbul adalah peserta didik kelas VII SMPLB-C dapat membuat tas untuk suvenir namun masih dalam bimbingan guru. Guru selalu menegur Ba disaat ia bercanda sehingga Ba sudah jarang bercanda dan mampu mengikuti kegiatan pembelajaran dengan baik. Ba mengalami peningkatan hasil belajar keterampilan tata busana materi pembuatan tas untuk suvenir sebesar $15,5 \%$. Peningkatan yang dialami Ba sudah maksimal dan sudah mencapai target melebihi $70 \%$.

Guru sering mendampingi $\mathrm{Pu}$ dan selalu mengajukan pertanyaan sehingga $\mathrm{Pu}$ menjadi fokus dan dapat mengikuti kegiatan pembelajaran dengan baik. $\mathrm{Pu}$ mengalami peningkatan hasil belajar keterampilan tata busana materi pembuatan tas untuk suvenir sebesar 15,4 \%. Peningkatan yang dialami Pu sudah maksimal dan sudah mencapai target melebihi $70 \%$. Berdasarkan hasil pada pengamatan siklus II, peneliti dan kolaborator melihat peningkatan peserta didik yang sudah optimal, karena dalam pembuatan tas untuk suvenir, peserta didik dapat 
mempraktikan secara mandiri. Berikut adalah grafik peingkatan hasil belajar siswa tata busana dalam materi pembuatan tas untuk suvenir dengan model pembelajaran eksplisit.

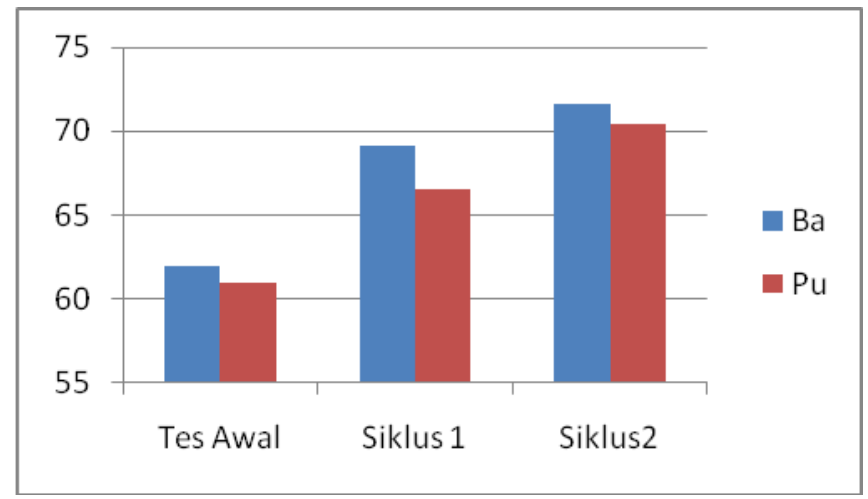

Gambar 1. Grafik Peningkatan Hasil Belajar Siswa Tata Busana

Keberhasilan penelitian disimpulkan dengan menggunakan hasil persentase pada siklus terakhir dimana persentase keterampilan peserta didik melebihi $70 \%$, ini berarti hasil belajar keterampilan tata busana materi pembuatan tas untuk suvenir pada anak tunagrahita ringan dapat meningkat setelah menggunakan model explicit instruction.

Berdasarkan hasil penilaian dari siklus I, terdapat peningkatan hasil belajar keterampilan tata busana materi pembuatan tas untuk suvenir. Dengan demikian terdapat peningkatan hasil belajar keterampilan tata busana materi pembuatan tas untuk suvenir tetapi belum mencapai lebih dari $70 \%$.

Sedangkan pada hasil penilaian dari siklus II, terdapat peningkatan hasil belajar keterampilan tata busana materi pembuatan tas untuk suvenir. Berdasarkan perhitungan persentase, hasil belajar keterampilan tata busana materi pembuatan tas untuk suvenir pada anak tunagrahita ringan sudah lebih dari 70\%. Dengan demikian, peningkatan hasil belajar keterampilan tata busana materi pembuatan tas untuk suvenir sudah maksimal.

\section{Pembahasan}

Berdasarkan hasil perhitungan persentase memperlihatkan peningkatan hasil belajar keterampilan tata busana materi pembuatan tas untuk suvenir. Dengan demikian model pembelajaran eksplisit mempunyai pengaruh dalam meningkatkan hasil belajar keterampilan tata busana materi pembuatan tas untuk suvenir pada anak tunagrahita ringan.

Berdasarkan pembahasan siklus I dan II maka dapat disintesiskan temuan penelitian sebagai berikut: 
1. Kemampuan motorik anak tunagrahita yang rendah dalam melakukan kegiatan praktikum, Ba melakukan kegiatan dengan ragu dan $\mathrm{Pu}$ melakukannya dengan kurang hati-hati, hal ini dikarenakan kemampuan motorik mereka yang kurang sehingga mengalami kesulitan dalam melakukan kegiatan psikomotor. Kemampuan motorik yang kurang oleh karena banyak kerusakan sel otak, anak tunagrahita mengalami gangguan motorik. Ia tidak dapat bergerak dengan tepat, kaku, dan koordinasi motorik tidak baik. Kekurangan ini dapat terlihat pada cara berjalan, lari, lompat, melempar, menulis, memotong dan pekerjaan lainnya (Astati 2011).

2. Ba peserta didik yang suka mengganggu temannya. Ba anak yang sangat senang sekali bercanda sehingga ia sangat senang mengganggu orang di sekelilingnya sehingga perhatiannya mudah sekali teralihkan. Perhatian anak tunagrahita hanya berlangsung sebentar. Ia mudah merasa lelah, bosan dan akhirnya mengalihkan perhatiannya ke hal-hal yang lain. Ia mudah terangsang oleh sesuatu yang ada disekitarnya sehingga mengganggu anak lain (Astati 2011). 3. Pembelajaran anak tunagrahita harus menggunakan prinsip keperagaan, pengulangan dan individualisasi. Anak tunagrahita mengalami hambatan dalam menerima informasi. Mereka akan cenderung diam saja jika hanya dinstruksikan dan diperagakan sekali. Hal ini membuat guru mengeluarkan tenaga ekstra untuk menghadapi mereka. Guru tunagrahita harus mempunyai jiwa penyabar dalam menghadapi anak tunagrahita. Karakteristik guru yang dapat menunjang terciptanya hubungan sosio-emosional adalah disukai siswa, memiliki persepsi yang realistik tentang dirinya dan siswanya, akrab dengan siswa dalam batasan hubungan guru-siswa, bersikap positif terhadap pernyataan siswa, serta sabar, teguh, dan tegas (Sri Widati 2011).

\section{SIMPULAN}

Berdasarkan hasil penelitian, dapat terlihat adanya peningkatan hasil belajar keterampilan tata busana materi pembuatan tas untuk suvenir pada peserta didik kelas VII SMPLB-C Negeri 1 Yogyakarta. Hal ini dapat terlihat dari pengamatan dan penilaian pada penelitian. Dengan demikian, dapat dikatakan bahwa penelitian ini berhasil karena adanya peningkatan hasil belajar keterampilan tata busana materi pembuatan tas untuk suvenir pada anak tunagrahita ringan kelas VII SMPLB-C Negeri 1 Yogyakarta. Peningkatan ini disebabkan oleh penggunaan model pembelajaran eksplisit yang membuat peserta didik mengetahui langkah-langkah membuat tas untuk suvenir dan pembelajaran yang berulang-ulang sehingga peserta didik mampu membuat tas untuk suvenir secara mandiri. 


\section{DAFTAR PUSTAKA}

Apriyanto, N. (2012) Seluk-Beluk Tunagrahita dan Strategi Pembelajarannya. Jogjakarta: JAVALITERA

Astati. (2011). Bina Diri Untuk Anak Tunagrahita. Bandung: Amanah Offset Astati. (2011). Pendidikan Anak Tunagrahita. Bandung: Amanah Offset

Jamaris, M. (2010). Orientasi Baru Dalam Psikologipendidikan. Jakarta: Yayasan Panamas Murni

Somantri, S . (2007). Psikologi Anak Luar Biasa. Jakarta: Refika Aditama

Syah, M. (2009). Psikologi Pendidikan Dengan Pendekatan Baru. Bandung: Remaja Rosda Karya

Trianto. (2010). Mendesain Model Pembelajaran Inovatif Progresif. Jakarta: Kencana

Widati, S. (2011). Pembelajaran Kreatif Dalam Pendidikan Anak Berkebutuhan Khusus. Bandung: Amanah Offset. 